\title{
SOME NEW RETARDED VOLTERRA-FREDHOLM TYPE INTEGRAL INEQUALITIES WITH POWER NONLINEAR AND THEIR APPLICATIONS
}

\author{
QING-HUA MA AND JOSIP PEČARIĆ
}

Abstract. Some new explicit bounds on solutions to a class of new nonlinear retarded VolterraFredholm type integral inequalities are established, which can be used as effective tools in the study of certain integral equations. Applications examples are also indicated.

Mathematics subject classification (2000): 26D10, 26D15, 45G10. equations.

Key words and phrases: Nonlinear retarded inequality, explicit bound, Volterra-Fredholm type integral

\section{REFERENCES}

[1] D. Bainov, P. Simeonov, Integral Inequalities and Applications, Kluwer Academic Publishers, Dordrecht, 1992.

[2] W. S. ChEUnG, Q. H. MA, Nonlinear retarded integral inequalities for functions in two variables, J. Concr. Appl. Math., 2, (2004), 119-134.

[3] W. S. ChEUNG, Q. H. MA, On certain new Gronwall-Ou-Iang type integral inequalities in two variables and their applications, J. Iequali. Appl., 8, (2005), 347-361.

[4] W. S. CHEUNG, Some new nonlinear inequalities and applications to boundary value problems, Nonlinear Analysis TMA, 64, (2006), 2112-2128.

[5] C. M. DAFERMOS, The second law of thermodynamics and stability, Arch. Rat. Mech. Anal., 70, (1979), $167-179$.

[6] F. C. JiAng, F. W. MenG, Explicit bounds on some new nonlinear integral inequalities with delay, J. Comput. Appl. Math., 205, (2007), 479-486.

[7] Y. H. KIM, On some new integral inequalities for functions in one and two variables, Acta Math. Sinica, English Series, 21, (2005), 423-434.

[8] V. Lakshmikantham, S. Leela, Differential and Integral Inequalities, Theory and Applications, Academic Press, New York, 1969.

[9] O. LIPOVAN, A retarded integral inequality and its applications, J. Math. Anal. Appl., 285, (2003), 436-443.

[10] O. Lipovan, A retarded Gronwall-like inequality and its applications, J. Math. Anal. Appl., 252, (2000), 389-401.

[11] W. N. Li, M. A. HAN AND F. W. MENG, Some new delay integral inequalities and their applications, J. Comput. Appl. Math., 180, (2005), 191-200.

[12] Q. H. MA, E. H. YANG, Some new nonlinear delay integral inequalities, J. Math. Anal. Appl., 252, (2000), 864-878.

[13] Q. H. MA, E. H. YANG, Some new Gronwall-Bellman-Bihari type integral inequalities with delay, Period. Math. Hungar., 44, (2002), 225-238.

[14] Q. H. MA, J. PEČARIĆ, Some new nonlinear retarded integral inequalities and their applications, Math. Inequal. Appl., 9, (2006), 617-632.

[15] F. W. Meng, W. N. LI, On some new integral inequalities and their applications, Appl. Math. Comput. , 148, (2004), 381-392. 
[16] D. S. Mitrinović, J. E. PeČARIĆ AND A. M. FInK, Inequalities Involving Functions and Their Integrals and Derivatives, Dortlrecht/Boston/London, Kluwer Academic Publishers, 1991.

[17] W. OKRASINSKI, On a nonlinear convolution equation occuring in the theory of water percolation, Ann. Polo. Math., 37, (1980), 223-229.

[18] L. Ou-IANG, The boundedness of solutions of linear differential equations $y^{\prime \prime}+A(t) y^{\prime}=0$, Shuxue Jinzhan, 3, (1957), 409-418.

[19] B. G. PACHPATTE, On a certain inequality arising in the theory of differential equations, J. Math. Anal. Appl., 182, (1994), 143-157.

[20] B. G. PACHPATte, Inequalities for Differential and Integral Equations, Academic Press, New York, 1998.

[21] B. G. PACHPATTE, Explicit bound on a retarded integral inequality, Math. Ineqal. Appl., 7, (1) (2004), $7-11$.

[22] Y. G. Sun, On retarded integral inequalities and their applications, J. Math. Anal. Appl., 301, (2005), 265-275.

[23] W. WANG, An algorithm for solving the high-order nonlinear Volterra-Fredholm integro-differential equation with machanization, Appl. Math. Comput., 172, (2006), 1-23.

[24] E. H. YANG, A new integral inequality with power nonlinear and its discrete analogue, Acta Math. Appl. Sinica, English Series, 17, (2001), 233-239.

[25] E. H. YANG, On some nonlinear integral and discrete inequalities related to Ou-Iang's inequality, Acta Math. Sinica, English Series, 14, (1998), 353-360.

[26] S. YALCINBAS, Taylor polynomial solutions of linear Volterra-Fredholm integral equations, Appl. Math. Comput., 127, (2002), 195-206. 